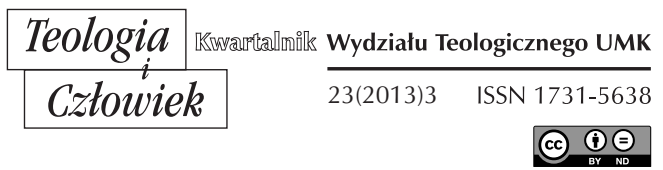

KS. DANIEL BRZEZIŃSKI*

TORUŃ-PŁOCK

\title{
AULA LITURGICZNA: KU PONOWNEMU ODKRYWANIU TEOLOGICZNO-LITURGICZNEGO SENSU
}

DOI: http://dx.doi.org/10.12775/TiCz.2013.037

\section{WPROWADZENIE}

Wydaje się, że architektura sakralna, zarówno w świecie, w Europie, jak i u nas w Polsce, wciąż przeżywa kryzys. Dotyczy on w dużej mierze przede wszystkim wnętrz naszych kościołów, w tym ukształtowania i wyposażenia auli liturgicznych. Gdy pytamy, dlaczego nie podobają się nam współczesne kościoły, nierzadko pada odpowiedź, że w nowo projektowanych wnętrzach dominuje zbyt „użytkowy" styl ${ }^{1}$. Czasem wynika on z zupełnego braku jakiejkolwiek całościowej i spójnej, architektoniczno-liturgiczno-teologicznej koncepcji wnętrza sakralnego, której rezultatem byłby szczegółowy projekt obejmujący i miejsce przewodniczenia liturgii, i strefę liturgii słowa Bożego, i strefę liturgii Ofiary, ale

* Ks. Daniel Brzeziński - prezbiter diecezji płockiej; dr hab. nauk teologicznych (spec. liturgika); absolwent Papieskiego Instytutu Liturgicznego św. Anzelma w Rzymie oraz Instytutu Sacrum Ministerium watykańskiej Kongregacji ds. Duchowieństwa; pracownik naukowy Uniwersytetu Mikołaja Kopernika w Toruniu.

${ }^{1}$ Zob. Czy podobaja nam się nasze kościoty? - ankieta, "Znak” 531 (1999) n. 8, s. $72-126$. 
także strefę sprawowania sakramentu chrztu świętego, czy sakramentu pokuty i pojednania.

Niestety, zbyt rzadko zauważa się dzisiaj, że przestrzeń wnętrza sakralnego nie może nie być wypadkową wzajemnych wpływów i powiązań ludzkiej twórczości z naturą świętej liturgii, wraz z całą jej symboliką ${ }^{2}$ i teologiczno-liturgicznym sensem. Gdyby projektanci kościołów lepiej znali teologię świątyni chrześcijańskiej, ze specjalnym uwzględnieniem historii i teologii wnętrza sakralnego, gdyby byli świadomi jego biblijnej i patrystycznej wymowy, i gdyby znali aktualnie obowiązujące normy liturgiczno-prawne z tejże teologii wynikające, pewnie wówczas sytuacja przedstawiałaby się inaczej i nie musielibyśmy być świadkami „nijakości” form artystycznych elementów wyposażenia współczesnych kościołów. Błędem jest tutaj nadawanie architekturze sakralnej cech tzw. „maksymalnej neutralności"3.

W naszym - z konieczności - syntetycznym opracowaniu odwołamy się do biblijnej i patrystyczno-teologicznej wymowy strefy liturgii słowa Bożego (czyli ambony) oraz strefy liturgii Ofiary Chrystusa (czyli ołtarza), aby - niejako na nowo - odkryć ich sens i symbolikę we wnętrzu sakralnym. Owa symbolika, ściśle związana z liturgicznymi funkcjami tych elementów auli liturgicznej, swoimi korzeniami sięga Pisma Świętego, a $\mathrm{w}$ epoce patrystycznej $\mathrm{i} \mathrm{w}$ wiekach średnich została rozwinięta i pogłębiona. I choć niekiedy - zwłaszcza w epoce średniowiecza - była to bardziej wykładnia alegoryczna niż symboliczna, tym niemniej wywarła ona pozytywny wpływ na architekturę sakralną minionych czasów. Dlaczego nie może być podobnie i w naszych czasach?

\section{BIBLIJNA I PATRYSTYCZNO-TEOLOGICZNA WYMOWA STREFY LITURGIl SŁOWA BOŻEGO}

Najprawdopodobniej początki chrześcijańskiej ambony, jako miejsca proklamacji słowa Bożego, to katedra biskupia - miejsce przewodniczenia liturgii, mające swoje korzenie zarówno w świecie pogańskich

2 Terminów „symbol” i „symbolika” używamy w niniejszym opracowaniu w szerokim (nie ściśle teologiczno-liturgicznym) znaczeniu.

${ }^{3}$ Zob. E. Gieysztor-Miłobędzka, Vaticanum II Tridentinum Versus. Relacje pomiędzy sztuka a liturgia, w: W. Leszczyński (red.), Sztuka a religia, Warszawa 1991, s. 41-63. 
szkół, jak i w liturgii synagogalnej ${ }^{4}$. W chrześcijaństwie ambona to topos liturgiczny proklamowanego i wyjaśnianego słowa Bożego w celebracji Paschalnego Misterium Chrystusa ${ }^{5}$.

Wśród wielu prób ustalenia etymologii terminu „ambona”, najbardziej rozpowszechnione stanowisko wskazuje na grecki czasownik anabainein oznaczający: „wstępować”, „wchodzić na górę (do góry)”, „wspinać się (na podwyższenie)”. Natomiast grecki rzeczownik „ambon” znaczy: coś wypukłego, posiadającego formę okrągłą, coś wynurzającego się w formie okrągłej; albo wręcz: górę, czy szczyt wzgórza. Podobnie łaciński termin „ambo, ambonis” oznacza: wypukłość przypominająca tarczę lub puklerz. Rozumienie terminu „ambona” jako miejsca podwyższonego spotykamy u św. Augustyna. To patrystyczne spojrzenie na ambonę uzupełnili niejako teologowie średniowieczni. Żyjący w IX wieku Walafridus Strabo nazwę „ambona” wywodzi od łacińskiego ambio („otaczać"): ambona to miejsce, które otacza z każdej strony tego, kto na nią wstępuje; i tak samo ten, kto wstępuje na ambonę, otacza ją i obchodzi. Z kolei, wspominany już, G. Durand „ambo” (jak sam tłumaczył: pulpit, od którego czyta się Ewangelię) utożsamiał z dwiema stronami stopni, po których wchodzi się na ambonę i obchodzi się ją dookoła (łac. ambo $=$ obydwaj $)^{6}$.

${ }^{4}$ Por. B. Nadolski, Ambona. Historia, znaczenie, symbolika, Kraków 2008, s. 7-9. Wielu badaczy ambonę wywodzi od katedr i trybun, z których nauczano - na przykład - w starożytnych szkołach filozoficznych. Katedra, podest, pulpit, czy też inne miejsce podwyższone jak bima (podwyższone - między innymi - dla lepszej słyszalności) znane były w żydowskiej przestrzeni synagogalnej. Podwyższona estrada znajdowała się również w małych wspólnotach domus ecclesiae (np. w Dura Europos); por. tamże, s. 10 -14; C. Capomaccio, Monumentum resurrectionis. Ambone e candelabro per il cero pasquale. Iconografia e iconologia del monumento nella cattedrale di Sessa Aurunca, Roma 1993, s. 3-17.

${ }^{5}$ Por. B. Nadolski, dz. cyt., s. 16. Na temat historycznych (także pozaliturgicznych) funkcji ambony zob. tamże, s. 17-18; C. Capomaccio, dz. cyt., s. 32-44; R. Walczak, Symbolika i wystrój świątyni chrześcijańskiej. Przewodnik po wspótczesnej architekturze wnetrz sakralnych wedtug soborowych dokumentów Kościota i aktualnego prawa kościelnego, Poznań 2005, s. 44-49. Warto odnotować w tym miejscu, że ambonie poświęcono III Międzynarodowy Kongres Liturgiczny, który odbył się w opactwie benedyktyńskim w Bose, w dniach 2-4 czerwca 2005 roku. Materiały z kongresu opublikowano w pracy zbiorowej: L'ambone, tavola della parola di Dio, Magnano 2006.

${ }^{6}$ Zob. C. Capomaccio, dz. cyt., s. 19-21. Inne łacińskie terminy używane w starożytności na oznaczenie ambony to między innymi: „pulpitum”, ,"tribunal”, ,"analogium", „suggestus (suggestum)”, „iube”, „locus superior”, "auditorium”, „locus excellentior”, "cancelli"; zob. tamże; por. V. Gatti, Liturgia e arte. I luoghi della celebrazione, Bologna 2001, s. 97-99; B. Nadolski, dz. cyt., s. 14-16. 
Tak więc, ambona to miejsce okazałe i podwyższone (i stąd koniecznie zaopatrzone w schody; nota bene od schodów wziął swoją nazwę graduał, psalm responsoryjny śpiewany na schodach prowadzących na ambonę). Taką ambonę polecił skonstruować w swoim kościele św. Cyprian, biskup Kartaginy, co wychwalał potem Grzegorz z Tours. Tak ambonę - jako miejsce podwyższone, na które się wchodzi - przedstawiono: w syryjskich Konstytucjach Apostolskich z około 380 roku po Chrystusie, w - opisującym liturgię papieską - Ordo Romanus I, w Ordo Romanus $\mathrm{V}$, i w wielu innych, znanych nam źródłach liturgiczno-patrystycznych ${ }^{7}$.

Ambona z pierwszych wieków chrześcijaństwa jest monumentem; monumentem jednym (choć posiadającym czasem dwie loże /dwa podesty/, z których jedna miała dodatkowo dwa pulpity: jeden do odczytywania pism Starego, a drugi - pism Nowego Testamentu, z wyjątkiem Ewangelii; drugi podest służył do proklamacji Ewangelii); monumentem zorientowanym (najczęściej na osi wschód-zachód) ku wschodowi (możliwa jest też orientacja: północ-południe); i monumentem wysokim (stąd jedna z nazw ambony: „pyrgos” - wieża; wieża w Piśmie Świętym to symbol połączenia tego, co na dole z tym, co w górze). W kontekście tego ostatniego stwierdzenia ambona była często odczytywana jako symbol góry wniebowstąpienia Pana, a także góry, z której Zbawiciel wygłosił swoje „Kazanie na górze”. Dodajmy na marginesie, iż góra w Piśmie Świętym (jak zresztą $\mathrm{w}$ wielu religiach) to miejsce, gdzie ziemia styka się $\mathrm{z}$ niebem; to miejsce zamieszkania Boga ${ }^{8}$. Przykładem takich starożytnych ambon są monumenty z rzymskich bazylik: św. Klemensa, św. Sabiny, czy też Najświętszej Maryi in Cosmedin. Niejednokrotnie przestrzeń ambony - jak ogród - była otoczona ogrodzeniem, które jeszcze wydatniej ukazywało jedność i jedyność ambony (z wieloma pulpitami) w całej auli świątyni. Wszak grób, w którym złożono Chrystusa, znajdował się w ogrodzie. "Ogród ambony", czy też ambona jako ikona ogrodu, nawiązuje do ogrodu, w którym Bóg umieścił pierwszych rodziców. W Edenie na ludzi spadła śmierć; w Ogrodzie Zmartwychwstania ludzie zostali obdarowani życiem9.

7 Zob. C. Capomaccio, dz. cyt., s. 21-32; B. Nadolski, Leksykon liturgii, Poznań 2006, s. $1258,1263$.

${ }^{8}$ Zob. X. Léon-Dufour, Stownik Nowego Testamentu, Poznań 1986, s. 280-281; M. Lurker, Stownik obrazów i symboli biblijnych, Poznań 1989, s. 62-63, 263-264.

${ }^{9}$ Zob. C. Valenziano, Ambone e candelabro. Iconografia e iconologia, w: Facoltà Teologica di Sicilia (red.), Gli spazi della celebrazione rituale, Milano 1984, s. 166-170; C. Capomaccio, dz. cyt., s. 44-63. 
Według Germana, patriarchy Konstantynopola żyjącego w I połowie VIII wieku, ambona jest ikoną Grobu Pańskiego, z którego Anioł odsunął kamień, czekając - po zmartwychwstaniu Chrystusa - na pobożne niewiasty, które przyszły namaścić Ciało umęczonego Zbawiciela. W proponowanej przez Germana wizji teologicznej, ambona symbolizuje również sam odsunięty kamień, ale także górę, z której głosi się Ewangelię. Podobnie Paweł Silentiarius, poeta i urzędnik kancelarii cesarskiej z czasów Justyniana, w poemacie z 563 roku zatytułowanym „Opis kościoła Mądrości Bożej", w ambonie bazyliki Hagia Sophia widział pusty Grób zmartwychwstałego Chrystusa (por. Mk 16,1-4). Ambona, więc, nie może być niczym innym, jak miejscem proklamacji Dobrej Nowiny o zbawieniu; miejscem apostolskiego i prorockiego głoszenia zmartwychwstałego Pana. Innymi słowy, ambona to symbol „zastępczej obecności Pustego Grobu"; ambona to miejsce skutecznej, misteryjnej obecności Ewangelii głoszonej całemu światu. Ambona to - obok kandelabru pod paschał - monumentum resurrectionis. Dlatego właśnie - wyjaśnia C. Valenziano - ambona jest dedykowana (także w sensie ikonograficznym) tym, którzy byli chronologicznie pierwsi w głoszeniu Dobrej Nowiny: kobietom idącym do Grobu, św. Piotrowi, św. Janowi, św. Marii Magdalenie, św. Pawłowi, czy wreszcie czterem Ewangelistom. Ze względu na Dobrą Nowinę ogłoszoną Dziewicy Maryi i na Dobrą Nowinę głoszoną przez Nią, zrozumiałe jest, że także Matka Najświętsza stała się „motywem” ikonograficznym na wielu ambonach ${ }^{10}$.

${ }^{10}$ C. Valenziano, dz. cyt., s. 163-165; V. Gatti, dz. cyt., s. 101-108; C. Capomaccio, dz. cyt., s. 69-93. W niektórych, zwłaszcza późniejszych świątyniach ambona wykonana została w kształcie łodzi na morskich falach. Ten biblijny obraz miał wyrażać Kościół miotany przeciwnościami, ale także Chrystusa nauczającego z łodzi. U Ojców Kościoła łódź jest często symbolem krzyża ze względu na maszt, który przypomina krzyż; zob. D. Forstner, Świat symboliki chrześcijańskiej. Leksykon, Warszawa 2001, s. 427. Również pulpit na ambonach przyjmujący kształt orła (stąd określenie: aquilinum) to nawiązanie do bogatej biblijno-patrystycznej symboliki orła. Jest on symbolem i formą objawienia się Boga. Z ambony przemawia i objawia się Bóg. Orzeł to także symbol zmartwychwstałego Chrystusa. Zazwyczaj przyzwyczailiśmy się łączyć symbol orła ze św. Janem Apostołem i Ewangelista, ale w przypadku ambony orzeł to przede wszystkim symbol Chrystusa, którego św. Jan kontempluje i doświadcza; zob. B. Nadolski, Ambona, s. 24-25. 


\section{BIBLIJNA I PATRYSTYCZNO-TEOLOGICZNA WYMOWA STREFY LITURGII OFIARY}

Podobnie jak z amboną, rzecz się ma z ołtarzem, który - wykonywany w najróżniejszych formach i kształtach oraz z wykorzystaniem różnych materiałów jako budulec - znany jest we wszystkich religiach: przede wszystkim jako miejsce składania ofiary, ale także jako tron bogów i grób zmarłych. To, co Grecy rozumieli przez „bomos” i "eschara”, Rzymianie określali jako altare. Łacińskie altare nawiązuje do adolere (łac. spalać), przy czym klasyczna łacina nie znała wyrażenia altare. Stosowano w niej natomiast terminy: altaria oraz ara, czyli "miejsce składania ofiar". Na określenie ołtarza stosowano także termin "mensa”, który oznaczał stół stawiany przed wizerunkiem danego bóstwa ${ }^{11}$.

Ołtarze odgrywały szczególną rolę w dziejach Narodu Wybranego, przede wszystkim w jego relacji do Jahwe. Po zniszczeniu Świątyni Jerozolimskiej, jednak, ołtarze w Izraelu - i ten całopalenia, i ten kadzielny - przestały istnieć. Historia ołtarzy Nowego Testamentu ma swój początek w Wieczerniku i na drzewie Krzyża ${ }^{12}$. W Nowym Testamencie odnajdujemy dwa terminy na oznaczenie ołtarza: "thysiasterion” (łac. altare) $\mathrm{i}$ "trapedza (trapeza)" (łac. mensa) ${ }^{13}$.

Ołtarze chrześcijańskie pierwszych wieków, zwłaszcza te w domus ecclesiae, najprawdopodobniej były zwykłymi stołami używanymi w starożytności (często trójnożnymi o okrągłym lub kwadratowym blacie, wykonanymi z marmuru, brązu lub drewna), na których dokonywano fractio panis. W katakumbach za ołtarz służyły płyty nagrobne z grobów męczenników, co stało się zalążkiem wznoszenia ołtarzy nad grobem męczenników, a potem - także obowiązkowego umieszczania w mensie ołtarza portatylu z relikwiami męczenników. Pierwsze ołtarze stałe były budowane w Syrii, w tamtejszych świątyniach, jeszcze przed Edyktem Mediolańskim, co poświadczają Didascalia syryjskie z III wieku. W swej

${ }_{11}$ Zob. B. Nadolski, Misterium chrześcijańskiego ottarza, Kraków 2009, s. 17-47; S. Longosz, Nazwy ottarza chrześcijańskiego w literaturze patrystycznej, "Vox Patrum” 27 (2007) n. 50-51, s. 497-533.

${ }_{12}$ Zob. B. Nadolski, Misterium, s. 49-69; J. S. Pasierb, Ottarz chrześcijański: historia i symbolika, „Studia Theologica Varsaviensia” 6 (1968) n. 2, s. 17-27; Z. Wit, Ottarz chrześcijański miejscem ofiary i uczty (cz. 1), "Anamnesis” 48 (2007) n. 1, s. 40-45.

${ }^{13}$ Późniejszymi synonimami terminu „mensa” - w zależności od wyglądu i miejsca usytuowania - są: martyrium, memoria, titulus, testimonium, confessio, arca; terminy świadczące też o pewnej ewolucji wyglądu i rozumienia ołtarza. 
formie zbliżone do litery $\mathrm{C}$, były one odsunięte od ściany absydy, ale czasem zdarzało się, że ołtarz ściany absydy dotykał ${ }^{14}$.

Ojcowie Kościoła i pisarze chrześcijańscy przedstawiali różnorodną symbolikę ołtarza. Zwykle dzieli się ją na: typiczną (typologiczną), tropologiczną i anagogiczną. Pierwsza z nich dzieli się jeszcze na typiczno-dogmatyczną (upatrującą w ołtarzu symbol Chrystusa i Kościoła; Chrystus jest skałą i kamieniem węgielnym; por. 1 Kor 10,4; Mt 21,42; Ps 118,22-23) ${ }^{15}$ i typiczno-przedstawiającą (charakterystyczną dla Wschodu, widzącą w ołtarzu symbol krzyża, grobu Pańskiego, stołu z Ostatniej Wieczerzy, a nawet żłóbka, ponieważ Eucharystię wiązano nie tylko z męką Chrystusa, ale również z Jego dzieciństwem) ${ }^{16}$. Symbolika tropologiczna albo moralna, zasadniczo właściwa dla zachodniej myśli teologicznej (św. Augustyn, Laktancjusz, Sicard z Cremony, G. Durand), upatrywała w ołtarzu bądź symbol wiary, bądź symbol serca ludzkiego. Natomiast symbolika anagogiczna (nawiązująca do Ap 8,3-5), dość rzadka i występująca głównie na Wschodzie, traktowała ołtarz jako obraz ołtarza niebieskiego i tronu Bożego (tronu Chrystusa; Raban Maur, Sicard z Cremony) ${ }^{17}$.

Najpowszechniejszą symboliką ołtarza, jaka wpłynęła na sztukę sakralną - w tym na architekturę - jest symbolika chrystologiczna. Ołtarz ,jest Chrystusem, który się ofiaruje” (Walafryd Strabo; św. Cyryl Aleksandryjski), ,jest Synem Bożym" (św. Grzegorz Wielki), albo - jak twierdził św. Ambroży w De sacramentis - jest "formą ciała Chrystusa". U podstaw tego wyrażenia leży prawda o unii hipostatycznej: Człowieczeństwo Chrystusa zostało złączone osobowo, w sposób nierozdzielny, z Jego Bóstwem. ${ }^{18} \mathrm{~W}$ jednej z Prefacji Wielkanocnych dziękujemy, więc,

${ }^{14}$ Zob. B. Nadolski, Misterium, s. 71-114; tenże, Leksykon, s. 1093-1100; A. J. Nowowiejski, Wykład liturgii Kościoła Katolickiego, t. 1: Wiadomości wstępne, cz. 1: O środkach rozwinięcia kultu, Warszawa 1893, s. 258-318; P. Sorci, Per una teologia dell'altare, w: Facoltà Teologica di Sicilia (red.), dz. cyt., s. 63-76; V. Gatti, dz. cyt., s. 113-123.

${ }^{15}$ Chrystologiczna symbolika ołtarza ściśle łączy się z symboliką eklezjologiczną, w której ołtarz jest symbolem Kościoła, ponieważ Chrystus jest nie tylko skałą i kamieniem namaszczonym przez Ducha Świętego, ale Głową całego Kościoła (por. Kol 1,18).

${ }_{16}$ Zwolennikami symboliki ołtarza jako Krzyża Jezusa Chrystusa (ponieważ na nim uobecnia się Ofiara Jezusa Chrystusa na odpuszczenie grzechów), która mieści się w kluczu typiczno-reprezentatywnym, na Zachodzie byli: św. Tomasz z Akwinu oraz św. Bernard z Clairvaux; por. Benedykt XVI, Posynodalna Adhortacja Apostolska o Eucharystii, źródle i szczycie życia i misji Kościoła "Sacramentum Caritatis", Kraków 2007, n. 47, s. 57.

17 Por. A. J. Nowowiejski, dz. cyt., s. 259-260.

${ }_{18}$ Por. B. Nadolski, Misterium, s. 197-205. Warto dodać, ze Optat z Miléve, 
Bogu Ojcu za to, że Chrystus, „oddając się za nasze zbawienie, sam stał się Kapłanem, Ołtarzem i Barankiem Ofiarnym"19.

Praktyczną konsekwencją symboliki chrystologicznej stało się używanie kamienia przy wznoszeniu ołtarzy. Bernard de Parentinis jako argument na stawianie ołtarza z kamienia, przytaczał fakt pojmowania ołtarza jako symbolu grobu Pańskiego ${ }^{20}$. Poza tym, kamień - jak z kolei nauczał Aleksander z Hales w swojej Sumie Teologicznej - to materiał mocny i trwały ${ }^{21}$. Stawianie ołtarzy z kamienia - jak już wspomnieliśmy - wiąże się także z kultem męczenników ${ }^{22}$. Natomiast, gdy do budowania ołtarzy wykorzystywano drewno (po ustaniu okresu prześladowań tendencje takie czasem natrafiały jednak na pewne opory, nawet jeszcze na przełomie pierwszego i drugiego tysiąclecia), w architektonicznej praxis nawiązywano do faktu, że ołtarz to stół ${ }^{23}$.

Symbolika chrystologiczna ołtarza z pierwszych wieków chrześcijaństwa, tudzież wieków średnich, wyrażająca się w stwierdzeniu: „ołtarz to Chrystus", nawiązuje również do wizji ołtarza z Apokalipsy św. Jana,

należący do generacji św. Ambrożego, wychodząc z ontologii platońskiej, uważał, że ołtarz „nie jest formą Ciała Chrystusa, lecz tylko miejscem dla Ciała Chrystusa”.

19 Zob. Mszat Rzymski dla diecezji polskich, Poznań 1986, s. 41*.

${ }^{20}$ Por. J. S. Pasierb, dz. cyt., s. 21. Gdy chodzi o symbolikę Grobu Pańskiego, to uważano, że tak, jak Ciało Chrystusa zostało złożone w grobie wykutym w skale, podobnie Corpus Domini przechowywane powinno być w grobie, jakim jest kamienny ołtarz.

${ }^{21}$ Por. J. S. Pasierb, dz. cyt., s. 20-21.

${ }^{22}$ Należy wspomnieć w tym miejscu, że konstrukcja architektoniczna składająca się z ołtarza i grobu, czyli konfesja („konfesja” w ścisłym sensie teologiczno-architektonicznym oznacza podziemne pomieszczenie znajdujące się poniżej ołtarza, zawierające relikwie; powszechnie zaś rozumiana jest jako architektoniczna struktura w świątyni zbudowana nad grobem męczennika) przybierała różne formy i ewoluowała. Podziemny grób połączony bezpośrednio z ołtarzem występował do końca pierwszego tysiąclecia. $\mathrm{Z}$ czasem konfesje przybierały formy bardzo rozbudowane. Takie rozwiązania znajdujemy szczególnie w Rzymie; przykładem jest tu Bazylika św. Piotra. Budując ołtarze, podnoszono poziom posadzki nawy, który stanowił szeroki i widoczny dostęp do konfesji. Gdy nie można było zbudować ołtarza bezpośrednio nad grobem męczennika, wówczas umieszczano jego relikwie w mensie ołtarzowej lub pod samym ołtarzem. Kiedy ołtarz przybierał formę sarkofagu zaczęto nad nim budować kopuły wsparte na czterech kolumnach. Ołtarz składał się więc z trzech elementów: konfesji podołtarzowej, mensy i kopuły, czyli ciborium. Ozdoba ta podkreślała zaszczytną funkcję, jaką ołtarz pełnił w świątyni, zarazem wskazywała na jego rangę; zob. B. Nadolski, Leksykon, s. 673; G. Klaja, Ottarz w świetle teologii, Kraków 2008, s. 50-53.

${ }^{23} \mathrm{Od} \mathrm{V}$ wieku, i na Wschodzie, i na Zachodzie, znane były także ołtarze metalowe, które w gruncie rzeczy były ołtarzami z drzewa lub kamienia, obłożonymi metalem; por. B. Nadolski, Misterium, s. 88-95. 
w której Apostoł klarownie personifikuje ołtarz, który oznacza samego Zbawcę (por. Ap 16,7). Ołtarz ziemski jest symbolem Chrystusa nie tylko z tego powodu, że Chrystus ofiaruje się na nim, lecz dlatego, że będzie jedynym ołtarzem w rzeczywistości nieba i już jest nim w sakramencie Eucharystii $^{24}$.

Skoro ołtarz to Chrystus, to - w myśl nauczania św. Ignacego z Antiochii -ołtarz powinien być jeden, jak jedna jest Eucharystia, jeden jest kielich, jeden biskup wraz $\mathrm{z}$ diakonami, oraz jedno jest Ciało naszego Pana Jezusa Chrystusa ${ }^{25}$. Zgromadzeni wierni tworzą wspólnotę liturgiczną, pośród której - w centrum - znajduje się Chrystus-Ołtarz ${ }^{26}$.

Ten święty stół - otaczany przez wiernych - symbolizuje anamnetyczną obecność Chrystusa; to na nim, na ołtarzu, uobecniają się największe wydarzenia zbawcze: męka, śmierć i zmartwychwstanie Jezusa. To na tym stole, in mysterio, pod sakramentalnymi znakami dokonuje się to, czego człowiek nie jest w stanie dostrzec zmysłami. Stąd od samego początku chrześcijaństwa ołtarz stanowił centrum przestrzeni liturgicznej i centrum zgromadzenia wiernych; niekoniecznie w wymiarze geometrycznym, ale zawsze $\mathrm{w}$ sensie duchowym ${ }^{27}$. Dlatego bardzo istotny zawsze był (i jest) wybór miejsca dla stołu Pańskiego. Ołtarz - odpowiednio wkomponowany w przestrzeń kościoła, i odpowiednio wyeksponowany - scala ją i definiuje, wyrażając aktualną myśl teologiczną i duchowość liturgiczną ${ }^{28}$.

${ }^{24}$ Por. R. Walczak, dz. cyt., s. 54-55.

${ }^{25}$ Por. Ignacy Antiocheński, Do Kościoła w Filadelfii, w: Pierwsi świadkowie. Pisma Ojców Apostolskich, tłum. A. Świderkówna, red. M. Starowieyski, Kraków 1998 (=Biblioteka Ojców Kościoła, t. 10), s. 133.

${ }^{26}$ Por. J. Popiel, Wnętrze kościoła w świetle odnowionej liturgii, w: F. Blachnicki W. Schenk - R. Zielasko (red.), Wprowadzenie do liturgii, Poznań - Warszawa - Lublin 1967, s. 537.

${ }^{27}$ Por. R. Walczak, dz. cyt., s. 54-57; H. Nadrowski, Kościoły naszych czasów. Dziedzictwo i perspektywy, Kraków 2000, s. 197. Niestety, działo się to często z „niekorzyścią" dla drugiego, równie ważnego centrum: stołu słowa Bożego.

${ }^{28} \mathrm{Na}$ wybór miejsca pod ołtarz zawsze składało się kilka motywów teologicznych, które ściśle związane są z Eucharystią, a mianowicie: ofiara, uczta i eschatologia. Na lokalizację ołtarza najbardziej wpłynął ten ostatni motyw: ołtarz był ustawiany tak, aby modlitwy można było kierować ku wschodowi, skąd przyjdzie Chrystus. Ponadto wschód uznawano za "miejsce raju”. Dlatego stół Pański ustawiano często we wschodniej części świątyni; zob. G. Klaja, dz. cyt., s. 61; B. Nadolski, Misterium, s. 28-29. Chociaż koncepcja, forma i usytuowanie ołtarza zmieniały się na przestrzeni wieków, ołtarz mimo bogatej symboliki (ale i alegorii) - najczęściej był rozumiany jako święty stół, 
Ołtarz „ma być syntezą architektury”29, gdyż „oznacza środek ciężkości, wartości, hierarchii rzeczy. W muzyce istnieje klucz, diapazon, akord. Tę właśnie nutę stanowi ołtarz, miejsce konsekrowane par excellence" ${ }^{\prime \prime}$.

\section{ZAKOŃCZENIE}

Historia liturgii i historia architektury uczą nas, że ambona - jako miejsce podwyższone, pomnik i monumentum resurrectionis - zaświadcza o wzniosłości głoszonych $\mathrm{w}$ liturgii treści i o autorytecie przepowiadającego, którym jest sam Chrystus, co z kolei powinno przekładać się na odpowiednią formę zewnętrzną. Podobnie ołtarz - to symbol krzyża Chrystusa i zarazem stół Pana, do którego Zbawiciel zaprasza swój lud; ołtarz to sam Chrystus, którego męka, śmierć i zmartwychwstanie są obecne in mysterio podczas celebracji każdej Eucharystii.

Zarówno ambona, jak i ołtarz, nie mogą być pojmowane wyłącznie $\mathrm{w}$ aspekcie ich użyteczności, jak to - niestety - często występuje w dobie współczesnej. Oczywiście nie znaczy to w najmniejszym stopniu, że wymiar użytkowy, czyli praktyczność i wygodę - w tym ergonomię elementów wnętrza sakralnego - należy ignorować przy projektowaniu i wznoszeniu nowych kościołów i adaptacji do współczesnej liturgii wnętrz zabytkowych. Poprawność teologiczna, piękno i godność ambony, ołtarza i wszystkich innych elementów auli liturgicznej nie mogą oznaczać opozycji w stosunku do ich funkcjonalności. Wszak "celem architektury sakralnej - jak przypomniał w Sacramentum Caritatis Benedykt XVI - jest dostarczenie Kościołowi, który celebruje tajemnice wiary, a w szczegól-

który pełnił podwójną funkcję: ukazania Najświętszego Ciała Chrystusa i sprawowania samej Ofiary Paschalnej. Z czasem ołtarz zaczął przybierać kształty monumentalne, wraz z olbrzymim retabulum, licznymi obrazami, rzeźbami, dekoracjami i złoceniami. Szczyt takiej ekspozycji to czas kontrreformacji, a w historii sztuki - renesans, barok i rokoko. Z ołtarzem przez setki lat związane było bogactwo dekoracji, złocenia i kosztowności. Pojawiła się nawet argumentacja, że to bogactwo ma stawać się ofiarą ołtarzową. To zaciemniło właściwe pojmowanie ołtarza; por. H. Nadrowski, dz. cyt., s. 192-198.

${ }_{29}$ Por. T. Furdyna, Wnętrze świątyni. Uwagi praktyczne, "Anamnesis” 13 (1997/98) n. 2, s. 35 .

${ }^{30}$ M. E. Rosier-Siedlecka, Posoborowa architektura sakralna. Aktualne problemy projektowania architektury kościelnej, Lublin 1979, s. 224. 
ności Eucharystię, przestrzeni najbardziej dostosowanej do właściwego przebiegu czynności liturgicznych"31.

Sztuka liturgiczna - w tym architektura sakralna - bez wątpienia jest i zawsze powinna być znakiem nadprzyrodzonej Rzeczywistości. Jest i zawsze powinna być "szatą liturgii” (jak nazwał architekturę W. Świerzawski) posiadającą "swoją teologię i zasadę duchową". Sztuka liturgiczna to „kształt miłości” wobec liturgii, a w konsekwencji - wobec Pana Boga i wobec ludzi powołanych do zbawienia ${ }^{32}$.

Streszczenie. Wydaje się, że architektura sakralna, zarówno w świecie, w Europie, jak i u nas w Polsce, wciąż przeżywa kryzys. Dotyczy on w dużej mierze przede wszystkim wnętrz naszych kościołów, w tym ukształtowania i wyposażenia auli liturgicznych. Gdy pytamy, dlaczego nie podobają się nam współczesne kościoły, często pada odpowiedź, że w nowo projektowanych wnętrzach dominuje zbyt „użytkowy” styl.

W opracowaniu odwołano się do biblijnej i patrystyczno-teologicznej wymowy strefy liturgii słowa (czyli ambony) oraz strefy liturgii Ofiary (czyli ołtarza), aby - niejako na nowo - odkryć ich sens i symbolikę we wnętrzu sakralnym. Owa symbolika, ściśle związana z liturgicznymi funkcjami tych elementów auli liturgicznej, swoimi korzeniami sięga Pisma Świętego, zaś w epoce patrystycznej i w wiekach średnich została rozwinięta i pogłębiona. I choć czasem - zwłaszcza w epoce średniowiecza - była to bardziej wykładnia alegoryczna, niż symboliczna, tym niemniej wywarła ona pozytywny wpływ na architekturę sakralną minionych czasów.

Słowa kluczowe: aula liturgiczna; architektura; liturgia.

Abstract. Liturgical space: re-discovering its theological-liturgical sense. It is a wide-spread opinion that sacred architecture around the world,especially in Europe and Poland, is suffering a crisis. The nature of this crisis in most cases is thought to centre round the interiors of churches, both the form and elements of the liturgical space. When enquiry is made as to why there is such distaste regarding modern churches, the answer usually focusses in on the modern design of their interior, which is characterized by the dicates of what might be seen to be a functional style.

This paper seeks to study the elements of both a scriptural and patristic theology which illumines the liturgy of the Word (ambo) and the liturgy of Eucharist (altar), and assists in discovering anew their significance and symbolism in creating a sacred place. The symbolism that guides this, is fashioned by both liturgical

${ }^{31}$ Benedykt XVI, dz. cyt., n. 41, s. 52.

32 Por. W. Świerzawski, Szata Obecności Pana, "Anamnesis” 13 (1997/98) n. 2, s. $9-16$. 
function and biblical roots which is deepened and developed through different epochs of the Church, especially patristic and medieval times. The medieval times in turn, leant towards both an allegorical interpretation and explanation rather than a symbolic one, but nonetheless, for all its limitations, this principle had a positive and fruitful influence on the sacred architecture of previous times.

Keywords: liturgical space; architecture; liturgy. 